\title{
Soybean yield potential estimated in a central region of RS State, Brazil
}

\section{Estimativa do potencial de rendimento da soja na região central do RS}

\author{
Lilian Cris DALLAGNOL ${ }^{1}$; Crislaine Sartori SUZANA ${ }^{2}$
}

${ }^{1}$ Autor para correspondência - Mestranda em Agronomia, Programa de Pós-Graduação em Agronomia, Faculdade de Agronomia e Medicina Veterinária, Universidade de Passo Fundo. BR 285, São José | Passo Fundo/RS | CEP: 99052 900, Caixa Postal 611. E-mail: lilian.cris.dallagnol@gmail.com

${ }^{2}$ Mestranda em Agronomia, Programa de Pós-Graduação em Agronomia, Faculdade de Agronomia e Medicina Veterinária, Universidade de Passo Fundo. E-mail: crislaine_agronomia@hotmail.com

Recebido em: 29-06-2014; Aceito em: 29-05-2016

\begin{abstract}
Despite soybean global economic relevance, its yield levels vary greatly in time and space. The state of Rio Grande do Sul (RS) has a lower average soybean yield than the Brazilian average, except for its Central region, where high yields and the extension of cultivated areas have been highlighted. Thanks to tech nology, high-quality cultivars, and professionalization of farmers, soybean tends to increase yield after every season. However, adverse weather is one of the factors that limit yield potential. The influence of factors that limit yield can be better understood if the crop yield potential is known. Therefore, the aim of this study was to estimate soybean yield potential in the central region of RS, based on mathematical models using historical climate data. According to the observations, it was concluded that the model has the potential to set optimum sowing times based on agronomic aspects, besides allowing for the estimation of soybean maximum regional production, showing that there is still much to improve and adapt to obtain high yield in crop management.
\end{abstract}

Additional keywords: Glycine max (L.) Merrill; Loomis \& Williams; mathematical models; yield.

\begin{abstract}
Resumo
Apesar da relevância econômica mundial da soja, seus patamares de produtividade variam muito no tempo e no espaço. $\mathrm{O}$ Estado do Rio Grande do Sul (RS) apresenta média de rendimento da oleaginosa inferior à média brasileira, exceto na região central, onde as altas produtividades e a extensão de áreas cultivadas vêm destacando-se. Devido à tecnologia empregada, cultivares de qualidade e profissionalização dos agricultores, a tendência da sojicultura é de alcançar produtividades crescentes a cada safra; no entanto, as adversidades climáticas são alguns dos fatores que têm trazido limitações ao potencial produtivo. A influência dos fatores que restringem o rendimento pode ser mais bem compreendida se for conhecido o potencial de rendimento da cultura. Objetivou-se estimar o potencial de rendimento da cultura da soja na região central do RS com base em modelos matemáticos, por meio de históricos de dados climáticos. De acordo com as observações, conclui-se que o modelo possui potencialidade para definir épocas preferenciais de semeadura, tendo por base aspectos agronômicos e, ainda, permite estimar o teto produtivo regional para a soja, demonstrando que ainda há muito a se melhorar e adequar no manejo da cultura para altos rendimentos.
\end{abstract}

Palavras-chave adicionais: Glycine max (L.) Merrill; Loomis \& Williams; modelos matemáticos; produtividade;

\section{Introduction}

Although soybean is currently among the most relevant crops globally and in Brazil's economy (Peter \& Ruhoff, 2013), its yield levels are low and vary greatly in time and space. Brazil's soybean yield in the 2012/13 season was $2918 \mathrm{~kg} \mathrm{ha}^{-1}$, while Rio Grande do Sul's did not exceed $2640 \mathrm{~kg} \mathrm{ha}^{-1}$ (CONAB, 2013). However, the municipality of Tupanciretã, located in the central region of RS, has emerged as the largest soybean producer in the state, with 140,000 hectares of cultivated area, showing an average yield of $3000 \mathrm{~kg} \mathrm{ha}^{-1}$ in the same season (IBGE, 2013).

In global agribusiness, soybean production is among the economic activities that increased the most.
Increase can be attributed to several factors, such as the structuring of a large international market related to the trade of soy products; consolidation of soy as an important vegetable protein source, especially to meet growing demands of sectors related to products of animal origin; higher development and supply of technologies that made soybean production possible in various regions of the world (Lazzarotto, 2009). However, in most years, weather adversities have been a major factor for yield fluctuations and restrictions on crop yield potential (Cunha et al., 1999; Barni \& Matzenauer, 2002; Moraes et al., 2011). Rainfall, temperature and solar radiation are among the main climatic variables that affect yield (Montone et al., 2009). 
The influence of factors limiting yield can be better understood if the crop yield potential is known (Rambo et al, 2004). The difference between yield potential and actual yield provides the size of losses affecting the crop (Evans, 1983).

Therefore, the aim of this study was to estimate soybean yield potential in the central region of RS state, Brazil, based on mathematical models using historical climate data.

\section{Material and methods}

Data used as basis for the application of the model by Loomis \& Williams (1963) were obtained from the meteorological stations of the National Institute of Meteorology (INMET) and of the State of Rio Grande do Sul Meteorology Center (CEMET/RS). As INMET has no weather station in the municipality of Tupanciretã, climate data from the municipality of Cruz Alta, located $88 \mathrm{~km}$ from Tupanciretã, were used.

The municipality of Tupanciretã, which belongs to the "Missões" region, 2905'00"S latitude and $53 \div 51$ '00"W longitude, has humid subtropical climate, with total annual rainfall of $1890 \mathrm{~mm}$. Although rainfall is well distributed between seasons, it is important to note that, during summer, there is higher evaporative demand from the atmosphere due to higher solar radiation and air temperature. Potential evapotranspiration is $108 \mathrm{~mm}$ in winter and $316 \mathrm{~mm}$ in summer (CEMET/RS, 2013). In order to assess the influence of factors that may limit soybean yield, maximum crop yield potential was estimated using the model proposed by Loomis and Williams (1963), which considered the following factors: daily solar radiation (cal $\mathrm{cm}^{-2}$ ), total visible radiation (cal $\mathrm{cm}^{-2}$ ), intercepted radiation (cal $\left.\mathrm{cm}^{-2}\right)$, total quanta $\left(\mu \mathrm{E} \mathrm{cm}^{-2}\right)$, loss by albedo $\left(\mu \mathrm{E} \mathrm{cm}^{-2}\right)$, loss by inactive adsorption ( $\left.\mu \mathrm{E} \mathrm{cm}^{-2}\right)$, total quanta available for photosynthesis $\left(\mu \mathrm{E} \mathrm{cm} \mathrm{cm}^{-2}\right)$, $\mu$ moles $\left(\mu \mathrm{mol} \mathrm{cm}^{-2}\right)$, loss by respiration $\left(\mu \mathrm{mol} \mathrm{cm}^{-2}\right)$, carbohydrate net production ( $\left.\mu \mathrm{mol} \mathrm{cm}^{-2}\right)$, daily production $\left(\mathrm{g} \mathrm{m}^{-2}\right)$, additional inorganic matter (\%), total production potential $\left(\mathrm{g} \mathrm{m}^{-2}\right)$, total production potential ( $\mathrm{kg} \mathrm{ha}^{-1}$ day $^{-1}$ ), total biomass ( $\mathrm{kg}$ dry matter ha-1), grain production ( $\mathrm{kg} \mathrm{ha}^{-1}$ ) and grain yield (bag ha-1). Dry matter (DM) production was used to estimate yield, through climate data of solar radiation in the crop over the complete cycle. In addition, leaf area index (LAI), radiation use efficiency (RUE), soybean extinction coefficient $(k)$ and crop harvest index $(\mathrm{CHI})$ values are also needed.

For simulation and data application purposes, a 120-day hypothetical growth cycle was used to soybean. Sowing date was selected, according to agroclimatic zoning (Brasil, 2013), to November 1, with physiological maturity of 110 days after sowing (DAS) and harvest at 120 DAS. After knowing the sowing and crop establishment periods, average daily insolation data of a 10-year period were used to find global radiation values, according to methodology by Berlato (1971), considering latitude (Tupanciretã, RS) and months of the year.

Daily solar radiation, obtained through INMET, is expressed in sunshine hours, requiring conversion to solar radiation (cal $\mathrm{cm}^{-2}$ day $^{-1}$ ). Thus, day duration, earth's tilt, location latitude, and daily insolation data were used. Through daily solar radiation converted in (cal $\mathrm{cm}^{-2}$ day $^{-1}$ ), total visible radiation was calculated, taking into account that the latter is equal to $44.8 \%$ of the first (Loomis \& Williams, 1963). Therefore, the amount of total visible radiation intercepted by the crop was determined.

In order to estimate solar radiation interception by crop canopy, in cal $\mathrm{cm}^{-2}$, Beer's law equation was used, which considers photosynthetically active radiation (PAR), extinction coefficient (k), and LAl.

Crop daily leaf area index (LAI) was obtained according to Câmara (2000a) equations, which state that LAI increases until crop flowering (occurring at about 50 DAS), and tends to decrease closer to physiological maturity (110 DAS). Thus, a regression equation that allowed for knowing soybean leaf area daily variation was generated. In addition, the extinction coefficient of 0.52 was considered for the vegetative phase, while the extinction coefficient of 0.93 was considered for the reproductive phase, based on Procópio et al. (2003). Light extinction coefficient (k) is connected to leaf tilt angle and leaf disposition, along with $\mathrm{LAI}$, providing indication of the plant efficiency to intercept radiation (Rocha et al., 2009).

Having knowledge of the solar radiation intercepted by crop leaves, total quanta was determined through multiplication by a factor of 8.64 ( $\mu$ einstein $\mathrm{cal}^{-1}$ ), suggested by Loomis \& Williams (1963).

Of total quanta obtained, loss by albedo was deducted, which is characterized as the ratio between electromagnetic radiation reflected by the surface and incident electromagnetic radiation (Souza et al., 1999), obtaining a $15 \%$ value based on regional literature. Loss by inactive absorption was 10\% (Loomis \& Williams, 1963). Taking into account these deductions, total quanta available for photosynthesis was found and transformed into $\mu \mathrm{mol} \mathrm{cm}^{-2}$. Loss by plant respiration was also calculated, and the value of $33 \%$ was adopted (Loomis \& Williams, 1963), resulting in carbohydrate net production ( $\mu$ moles $\mathrm{cm}^{-2}$ ).

Daily production $\left(\mathrm{g} \mathrm{m}^{-2}\right)$ was obtained considering net production multiplied by $30 \%$, value related to the molecular weight of carbohydrate composition. It was also taken into account that $8 \%$ of net production consists of inorganic matter (Loomis \& Williams, 1963), and this amount was added to daily production, in order to obtain biomass total production potential $\left(\mathrm{g} \mathrm{m}^{-2}\right)$, which was converted into $\mathrm{kg} \mathrm{ha}^{-1}$ (multiplying by 10) to facilitate data analysis. In order to calculate grain production and yield, total biomass production was multiplied by the harvest index of $45 \%$.

\section{Results and discussions}

For productive potential and biomass accumulation estimation purposes, crop cycle to physiological maturity was considered, corresponding to approximately 110 days. Global radiation, temperature and 
rainfall weather conditions during the cycle can be observed in Figure 1.

Average radiation and temperature conditions of 10 years (INMET, 2013) for Tupanciretã region, simulating sowing on $1^{\text {st }}$ November and harvest in late February, were in the optimum range for crop devel- opment. Rainfall during the cycle, in general, was well distributed, with lower values in the reproductive phase compared to the vegetative phase. However, this did not negatively affect plant growth and development (Figure 1).

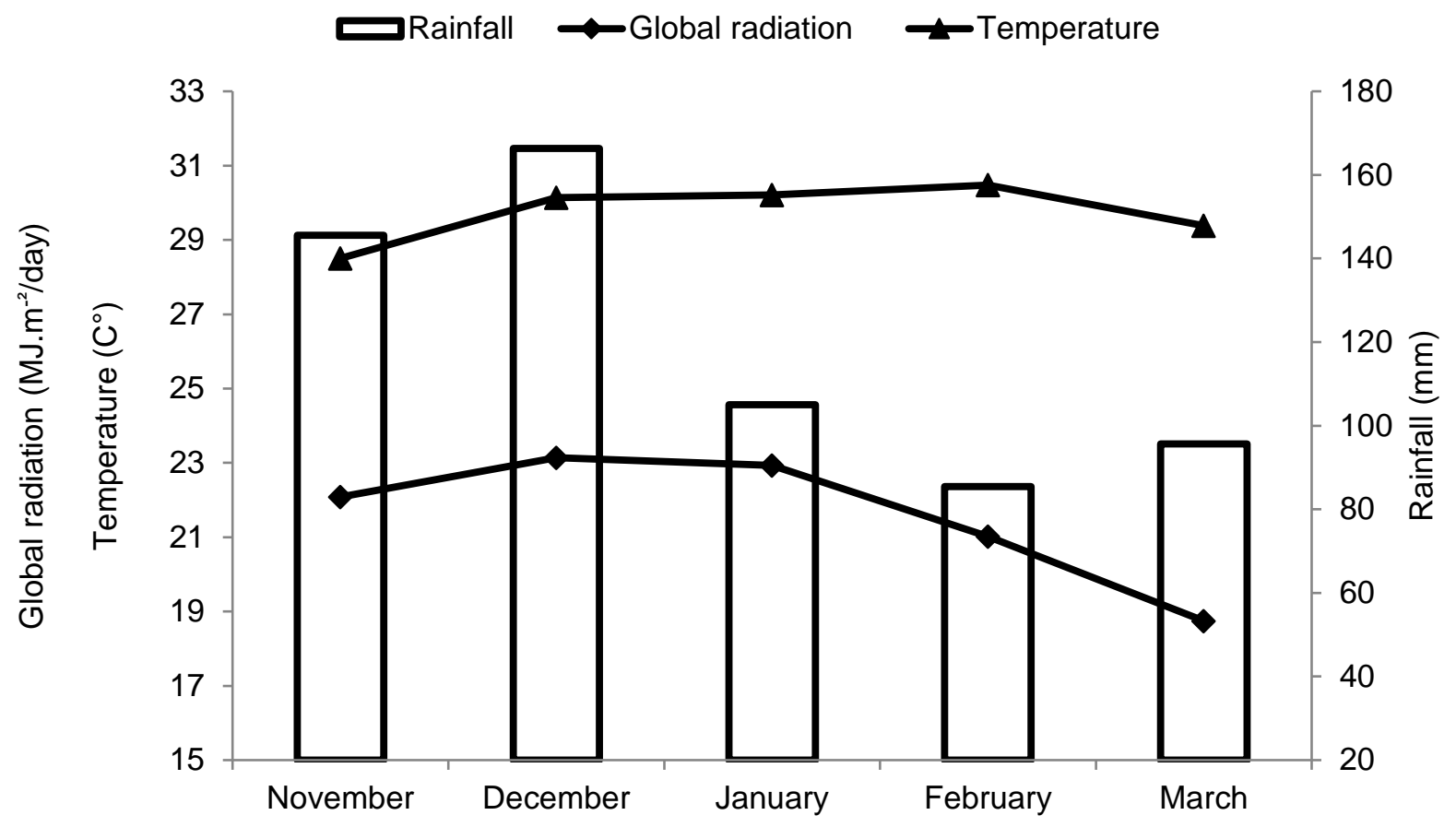

Figure 1 - Global radiation $\left(\mathrm{MJ} \mathrm{m}^{-2}\right.$ day $\left.^{-1}\right)$, temperature $\left({ }^{\circ} \mathrm{C}\right)$ and rainfall $(\mathrm{mm})$ obtained from averages of 10 years. Source: INMET Cruz Alta, RS.

The need for water in soybean increases with plant development, reaching its maximum during the flowering period until grain filling $\left(7-8 \mathrm{~mm}\right.$ day $\left.^{-1}\right)$, decreasing thereafter (Farias et al., 2007). Total water needs for maximum yield varies between $450-800 \mathrm{~mm} /$ cycle, depending on weather conditions, crop management and cycle length. Optimum rainfall to meet the needs during the critical phase (R1-R6), according to Farias et al. (2007), is between $120-300 \mathrm{~mm}$. Under Tupanciretã conditions, an average of $220 \mathrm{~mm}$ was obtained at this stage, totaling $600 \mathrm{~mm}$ during the entire cycle, which proves the possibility of achieving high yield potential with soybeans based on meteorological factors.

During the reproductive period, lack of adequate water amounts causes symbiotic activity decrease, flower and pod falling, grain abortion, smaller grain size, and reduced oil and protein contents. As a final result, raw material yield and quality reduction is observed (Costa, 2002). Therefore, it is essential to adjust the moments when climatic factors are needed the most by soybean with moments observed historically in the region

Sowing in November has not been used by producers in some situations (Rodrigues et al., 2002).
In RS state, early sowings (in the first half of October) in relation to the optimum crop time (November) are common, mainly aiming to avoid drought during periods when soybean requires more water. However, such early sowings (October) expose the crop to different photoperiod and temperature combinations, reflecting differentially in cycle duration (Rodrigues et al., 2001), grain growth rate (Rodrigues et al., 2006a), leaf area development (Rodrigues et al., 2006b), and solar radiation of cultivars, which may constitute an important cause of change in crop yield potential (Rodrigues et al., 2007).

For soybean, the best growing regions are those where air temperature is in the range from 20 to $30{ }^{\circ} \mathrm{C}$, with the optimum development value at $30^{\circ} \mathrm{C}$ (Farias et al., 2007). According to Battisti (2013), maximum temperature during flowering to grain filling (R1-R5.5) observed in Julio de Castilhos, RS, near the municipality of Tupanciretã, reached $39.5^{\circ} \mathrm{C}$ in the $2009 / 2010$ season, which is very close to the critical limit for this stage. Khan et al. (2011) observed that high temperatures $\left(35-43^{\circ} \mathrm{C}\right)$ during soybean reproductive period reduce the grain filling period and reserve accumulation in the seed. However, data shown by IBGE (2013) indicated high soybean yield in 
the region, showing that the temperature does not generally exercise negative influence on grain yield. The main variable affecting soybean yield in Brazil's producing areas is the water availability during the cycle. Based on data from the weather station, it can be seen that there is water availability reduction during soybean reproductive period in the region under study (Figure 1).

Solar radiation availability is among factors that most limit plant growth and development. In Tupanciretã, it was noted that radiation is uniform and sufficient for soybean development, peaking in the reproductive stages concentrated in December and January (Figure 1 and 2). All energy required to perform photosynthesis, process that converts atmospheric $\mathrm{CO}_{2}$ in metabolic energy, comes from solar radiation (Taiz \& Zieger, 2004). Solar radiation is closely related to soybean yield because it interferes with photosynthesis, main stem and branch elongation, leaf expansion, pod and seed setting, and nitrogen biological fixation (Câmara, 2000b).

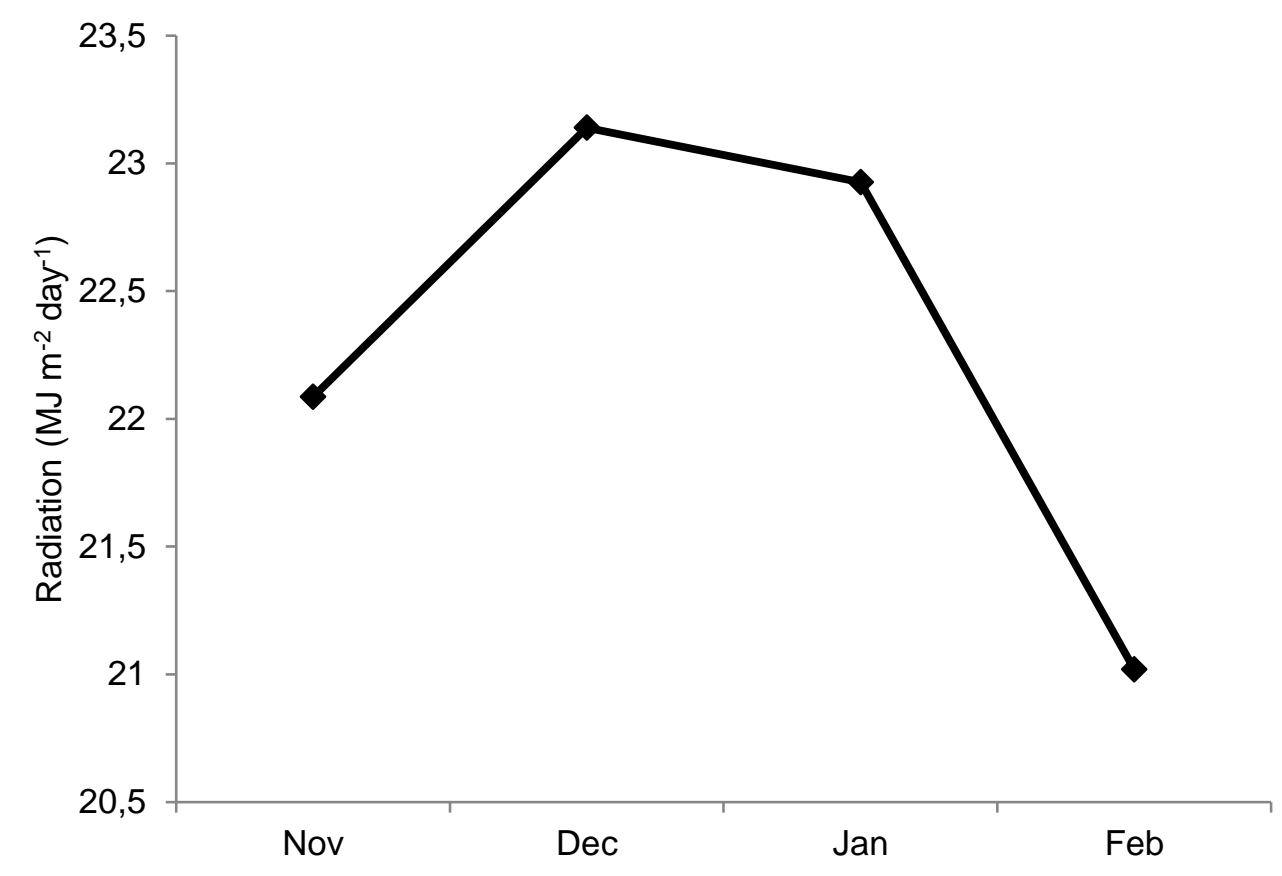

Figure 2 - Average global radiation (MJ $\mathrm{m}^{-2}$ day $^{-1}$ ) for the soybean crop cycle. Source: INMET Cruz Alta, RS.

Accumulated solar radiation values are related to total cycle duration. Battisti (2013) observed, for the same soybean cultivar, that the average cycle between sowing and physiological maturity was 94 days in New Fatima, PR, while it was 171 days in Uruguaiana, RS. The difference was attributed to solar radiation accumulated values of 1351 and $3139 \mathrm{MJ} \mathrm{m}^{2}$, respectively.

Gubiani (2005) observed the soybean cycle duration from sowing to physiological maturity (R7) for three periods (October, November and December). In general, early seeding (October) caused cycle extension, and delayed sowing (December) caused cycle reduction. Sowing time influence on thermal accumulation indicates that other environmental factors, such as day length and photoperiodic induction, interfere with phenological cycle (Camargo et al., 1987).

Overall, estimated intercepted radiation is directly related to LAI. In the reproductive period, when the plant has its maximum leaf number, the highest radiation interception values (Figure 3) are observed, corroborating with Lövenstein et al. (1995), who claimed that light interception by the canopy increases up to a certain critical value (critical LAI), when photosynthetically active radiation interception reaches its maximum. After the reproductive phase, LAI reductions occur, as leaves begin to senesce to translocate assimilates to the grains, a process that extends to physiological maturity (R7). Then, when critical LAI is reached, gross uptake rate is stabilized and growth rate becomes constant (Lövenstein et al., 1995). Light interception rate and its processing into dry matter depend on crop canopy geometrical and optical characteristics, which vary according to development and phenological stage (Lövenstein et al., 1995).

For Tupanciretã conditions, LAl increased from emergence $(E)$ to the pod stage (R4), when it reached its maximum value of $5.0 \mathrm{~m}^{2} \mathrm{~m}^{-2}$ (Figure 5). After the period of greatest demand for sources for assimilates accumulation (reproductive period), LAI decrease occurred, which is explained by assimilates redistribution (translocation) and plant senescence (Figure 3). According to Câmara (2000a), LAI increases linearly until the end of flowering, decreasing close to physiological maturity (R7). 


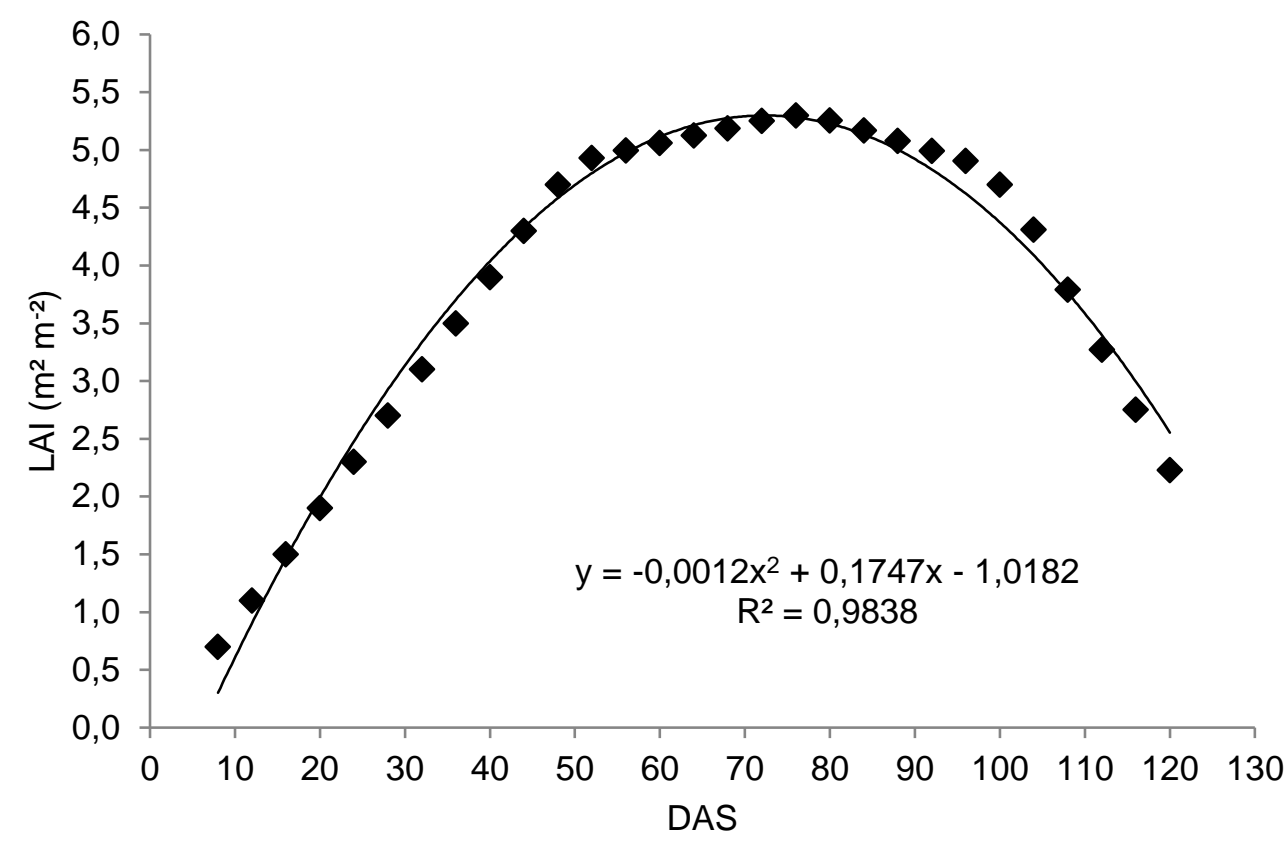

Figure 3 - Leaf area index $\left(\mathrm{m}^{2} \mathrm{~m}^{-2}\right)$ estimated in relation to days after sowing (DAS) of soybean.

A better LAI use, as a grain yield potentiating tool, can be obtained through management of genotypes of different maturity groups. In sowing periods when LAI is below the critical value, genotypes with late flowering and more time for leaf area development could be used (Rodrigues et al., 2006b).

Soybean production depends on canopy photosynthetic rate and this, in turn, depends on the maximum amount of intercepted solar radiation, which is around 95\% (Well, 1991). In order to obtain this interception amount, LAl should be between 3.5 to 4.0 $\mathrm{m}^{2} \mathrm{~m}^{-2}$ in the R1 stage (Board \& Harville, 1992). For Tupanciretã conditions, LAl of 4.0 and $5.0 \mathrm{~m}^{2} \mathrm{~m}^{-2}$ were obtained in the R1 and R4 stages, respectively, indicating plant adequacy in time and space, allowing the crop to have maximum environmental resource use and satisfactory biomass accumulation.

Solar radiation interception occurs depending on LAI and light extinction coefficient (Pengelly et al., 1999). With LAI increase, radiation interception increase occurs up to a certain value (Casaroli et al., 2007). At this time, self-shading is also increased, resulting in light extinction coefficient increase, which may range between 0.5 and 0.6 for soybean, considering the average cycle (Pengelly et al. 1999; Pereira et al, 2002).

Radiation intercepted by soybeans estimated to Tupanciretã was directly related to LAl. The higher the LAl, the higher the photosynthetically active area and, thus, total dry matter yield (Figure 4). It was noticed that, when LAI begins to decrease, dry matter generally remains constant. It is explained by translocation of photoassimilates, which were present in the leaves before, but were redirected to the grains with maturation. According to Monteith et al. (1965), dry matter accumulated by the crop is related to solar irradiation amount, interception percentage, and crop conversion efficiency. Andrade et al. (2002) observed that solar irradiance intercepted during the critical period of soybean yield components formation had a good relationship with grain yield. In addition, it was also observed that sowing management, plot spacing, and plant population should be planned, so that the crop could intercept more than $90 \%$ of available solar irradiation until the beginning of legume formation (R3).

The amount of energy accumulated in biomass depends on the captured solar energy amount and its efficient use (Loomis \& Williams, 1963). Studies on potential (or actual) solar energy use efficiency follow a general pattern. The destination of a solar radiation unit in a plant community is drawn through a series of "processes" or steps, ending with locally produced biomass (Amthor, 2010).

Muller et al. (2007) observed radiation use efficiency (RUE) reduction in late sowings. Average RUE estimated for the Tupanciretã region was $3.36 \mathrm{~g} \mathrm{MJ}^{-1}$, considered high compared with the literature. Probably, this is the result of Loomis \& Williams (1963) model overestimation of values. Casaroli et al. (2007) commented that soybean RUE gradually increases with leaf increase until R1 and R2 stages, reaching around $1.2 \mathrm{~g}$ of dry matter per MJ of photosynthetically active radiation intercepted by the canopy. In addition, when the air temperature is extreme, there may be losses in the process, reducing net $\mathrm{CO}_{2}$ assimilation. Radiation used by plants for photosynthesis is in the visible light range $(400 \mathrm{~nm}-700$ $\mathrm{nm}$ ), corresponding to $45 \%-50 \%$, approximately, of total incident radiation (Ometto, 1981). 


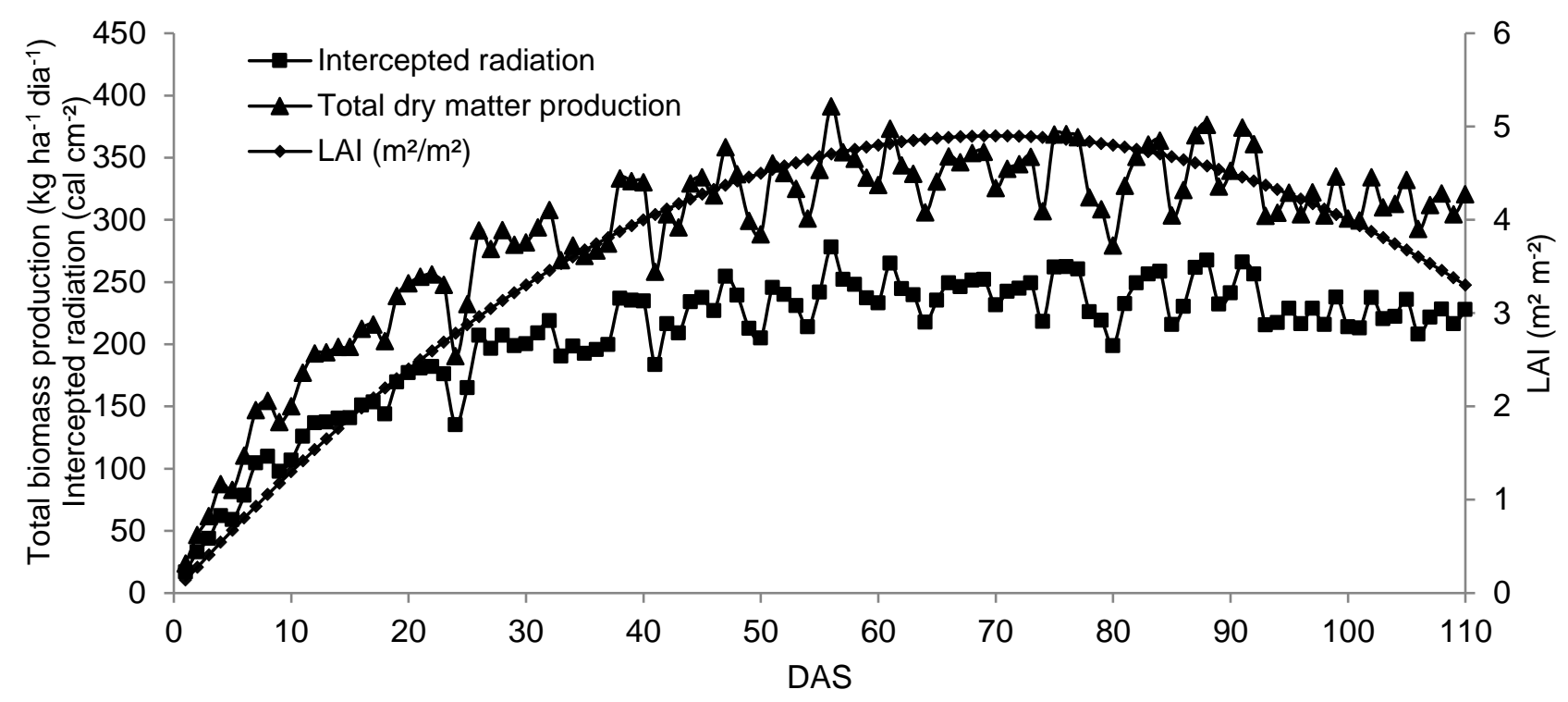

Figure 4 - Total biomass production $\left(\mathrm{kg} \mathrm{ha}^{-1}\right.$ day $\left.^{-1}\right)$, intercepted radiation $\left(\mathrm{cal} \mathrm{cm}^{-2}\right)$ and leaf area index $\left(\mathrm{m}^{2} \mathrm{~m}^{-2}\right)$ in relation to days after sowing (DAS).

Total biomass production and soybean yield were estimated during the 110-day cycle by Loomis \& Williams (1963) model, which included from sowing to physiological maturity, moment at which assimilate accumulation is ceased. Values obtained in this study are considered very high (Table 1). However, it is known that Loomis \& Williams (1963)' model ignores several yield limiting factors. In this context, Battisti (2013), in a ranking of soybean average yield in different locations and seasons, found that Julio de Castilhos, RS, a municipality near Tupanciretã, was first among the 23 municipalities studied, with $4972 \mathrm{~kg} \mathrm{ha}^{-1}$, showing soybean high yield potential in the region.

Table 1 - Estimated values for total biomass production and grain yield in Tupanciretã-RS, based on the potential estimation model yield Loomis \& Williams (1963).

\begin{tabular}{cc}
\hline Variable & Estimated value \\
\hline Total biomass production & $31.762,96$ \\
Grain yield $\left(\mathrm{kg} \mathrm{ha}^{-1}\right)$ & $12.705,18$ \\
Grain yield $\left(\right.$ bag ha $\left.^{-1}\right)$ & 211,75 \\
\hline
\end{tabular}

Gubiani (2005) observed the dry matter produced by soybean shoots in three sowing periods (October, November and December). Soy sown in November had the highest biomass accumulation in vegetative, reproductive and maturity periods, indicating that the sowing period estimated in this study was adequate. Thus, the highest grain yield achieved in November is caused mainly by large solar energy availability in the environment during the plant phenological cycle, in addition to favorable photoperiodic and thermal conditions, providing higher dry matter accumulation in shoot organs, which are converted in high yield (Gubiani, 2005).

\section{Conclusion}

The use of the yield potential estimation model by Loomis \& Williams (1963), based on historical weather data and adapted to include the daily LAI, although overestimating yield values, has the potential to set optimum sowing times based on agronomic aspects, besides allowing for the estimation of soybean maximum regional production, showing that there is still much to improve and adapt to obtain high yields in crop management.

\section{References}

Amthor JS (2010) From sunlight to phytomass: on the potential efficiency of converting solar radiation to phyto-energy. New Phytologist 188:939-959. (doi:10.1111/j.1469-8137.2010.03505.x)

Andrade FH, Calviño P, Cirilo A, Barbieri P (2002) Yield responses to narrow rows depend on increased radiation interception. Agronomy Journal 94(5):975-980.

Barni NA, Matzenauer R (2000) Ampliação do calendário de semeadura da soja no Rio Grande do Sul pelo uso de cultivares adaptados aos distintos ambientes. Pesquisa Agropecuária Gaúcha 6(2):189-203.

Battisti R (2013) Épocas de semeadura da cultura da soja com base no risco climático e na rentabilidade líquida para as principais regiões produtoras do Brasil. USP (Dissertação de mestrado).

Board JE, Harville BG (1992) Explanations for greater light interception in narrow-vs. wide-row. Crop Science 32:198-202. 
Câmara GMS (2000a) Bases de fisiologia da cultura da soja. ESALQ/DPV. 21p.

Câmara GMS (2000b) Soja: tecnologia da produção II. G.M.S. Câmara. 450p.

Camargo MBP, Brunini O, Miranda MAC (1987) Temperatura-base para cálculo dos graus-dia para cultivares de soja em São Paulo. Pesquisa Agropecuária Brasileira 22(2):115-121.

Casaroli D, Fagan EB, Simon J, Medeiros SP, Manfron PA, Dourado-Neto D, Jong Van Lier Q, Müller L, Martin TN (2007) Radiação solar e aspectos fisiológicos na cultura de soja: uma revisão. Revista da FZVA 14:102-120.

CONAB (2013) Séries históricas. Available at: $<$ http://www.conab.gov.br/conteudos.php?a $=1252 \& \mathrm{t}=2$ \&Pagina_objcmsconteudos=2\#A_objcmsconteudos.> (accessed jun 20 2013).

Costa JA (2002) Rendimento da soja: chegamos ao máximo? Informações Agronômicas 99(1):1-6.

Cunha GD, Hass JC, Dalmago GA, Pasinato A (1999) Cartas de perda de rendimento potencial em soja no Rio Grande do Sul por deficiência hídrica. Embrapa Trigo. 52p.

Evans JR (1983) Nitrogen and photosynthesis in the flag leaf of wheat (Triticum aestivum L.). Plant Physiology 72(2):297-302.

Farias JRB, Neumaier N, Nepomuceno AL (2007) Exigências climáticas. Available at:

<bioinfo.cnpso.embrapa.br/seca/index.php/ecofisiolo gia/exigências-

climaticas?tmpl=component\&print $=1$ \&page $=>$

(Accessed jun 22 2013).

Gubiani El (2005) Crescimento e rendimento da soja em resposta a épocas de semeadura e arranjo de plantas. UFRGS (Dissertação de mestrado).

IBGE -- Instituto Brasileiro de Geografia e Estatistica (2013) @Cidades. Available at: <http://www.ibge.gov.br> (Accessed jun 22 2013).

Khan AZ, Shah P, Khan H, Nigar S, Perveen S, Shah MK, Amanullah, Khalil SK, Munir S, Zubair M (2011) Seed quality and vigor of soybean cultivars as influenced by canopy temperature. Pakistan Journal of Botany 43(1):643-648.

Lazzarotto JJ (2009) Evolução e perspectiva de desempenho econômico associados com a produção de soja nos contextos mundial e brasileiro. Embrapa Soja 319:2176-2937.

Loomis RS, Williams WA (1963) Maximum crop productivity: an estimate. Crop Science 3(1):67-72.

Lövenstein $\mathrm{H}$, Lantinga EA, Rabbinge $\mathrm{R}$, Van Kuelen $H$ (1995) Principles of production of ecology. Agricultural University of Wageningen. 121p.
Monteith JL (1965) Light distribution and photosynthesis in field crops. Annals of Botany 20:17- 37.

Montone VO, Marin FR, Farias JRB (2009) Parametrização de um modelo para estimativa da produtividade de soja para as regiões sul e centrooeste do Brasil. In: CONGRESSO BRASILEIRO DE AGROMETEOROLOGIA, 16, 2009, Belo Horizonte. Anais... Viçosa, MG: UFV; Sete Lagoas: Embrapa Milho e Sorgo, 2009.

Moraes WB, Junior WCJ, Moraes WB, Cecílio RA (2011) Potenciais impactos das mudanças climáticas globais sobre a agricultura. Revista Trópica - Ciências Agrárias e Biológicas 5(2):3-14.

Muller AG, Berto JL, Toledo NT (2007) Modelagem Matemática do Acúmulo da Massa Seca em soja. In: CONGRESSO NACIONAL DE MATEMATICA APLICADA E COMPUTACIONAL, 30, 2007. Florianópolis. Anais eletrônicos... Florianópolis: SBMAC, 2007. Disponível

em:<www.sbmac.org.br/eventos/cnmac/xxx_cnmac/P DF/87.pdf>. (Acesso em: jun. 2013).

Ometto JC (1981) Bioclimatologia vegetal. Editora Agronômica Ceres. 425p.

Pengelly BC, Blamey FPC, Muchow RC (1999) Radiation interception and the accumulation of biomass and nitrogen by soybean and three tropical annual forage. Field Crops Research 63(1):99-112.

Pereira AR, Angelocci LR, Sentelhas PC (2002) Agrometeorologia: fundamentos e aplicações práticas. Agropecuária. $478 \mathrm{p}$.

Peter AR, Ruhoff AL (2013) Análise do comportamento de NDVI e NDWI para a cultura da soja no município de Tupanciretã-RS nas safras de 2000-2001 e 20042005. Anais XVI Simpósio Brasileiro de Sensoriamento Remoto, Foz do Iguaçú.

Procópio SO, Silva EAM, Silva AAEAF (2003) Anatomia foliar de plantas daninhas do Brasil. Viçosa: Edição dos autores. 118 p.

Rambo L, Costa JÁ, Pires JLF, Parcianello G, Ferreira FG (2004) Estimativa do potencial de rendimento por estrato do dossel da soja, em diferentes arranjos de plantas. Ciência Rural 34(1):33-40.

Rodrigues O, Didonet AD, Lhamby JCB, Bertagnolli PF (2001) Rendimento de grãos de soja em resposta à época de semeadura. Passo Fundo: Embrapa Trigo. 3 p. html (Embrapa Trigo. Comunicado técnico online, 65). Disponível em: <http://www.cnpt.embrapa.br/biblio/p_co65.htm>.

(Acesso em: jun. 2013). 
Rodrigues O, Didonet AD, Lhamby JCB, Teixeira MCC, Guareschi R (2006a) Efeito da temperatura e do fotoperíodo na duração e na taxa de crescimento de grãos de soja. Passo Fundo: Embrapa Trigo. 28p. html (Embrapa Trigo. Boletim de pesquisa e desenvolvimento online, 35). Disponível em: <http://www.cnpt.embrapa.br/biblio/bp/p_bp35.htm>. (Acesso em: jun. 2013).

Rodrigues O, Teixeira MCC, Lhamby JCB, Bonato ER, Bertagnolli PF (2002) Sistema tardio de semeadura de soja (STS). Passo Fundo: Embrapa Trigo. 16 p. html. (Embrapa Trigo. Circular Técnica Online; 11). Disponível: <http://www.cnpt.embrapa.br/biblio/p_ci11.htm> (Acesso em: jul. 2013).

Rodrigues O, Teixeira MCC, Costenaro ER, Bertagnolli PF (2007) Avaliação de cultivares de soja transgênica (BRSRR) em sistema precoce de semeadura (SPS). Passo Fundo: Embrapa Trigo. 30 p. HTML (Embrapa Trigo. Boletim de pesquisa e desenvolvimento online, 45). Disponível em: <http://www.cnpt.embrapa.br/biblio/bp/p_bp45.htm>. (Acesso em: jun. 2013).
Rodrigues $\mathrm{O}$, Teixeira MCC, Didonet AD, Lhamby JCB, Sório I (2006b) Efeito do fotoperíodo e da temperatura do ar no desenvolvimento da área foliar em soja (Glycine max (L.) Merril). Passo Fundo: Embrapa Trigo. 27 p. html (Embrapa Trigo. Boletim de pesquisa e desenvolvimento online, 33). Disponível em: <http://www.cnpt.embrapa.br/biblio/bp/p_bp33.htm>. (Acesso em: jun. 2013).

Taiz L, Zieger E (2004) Fisiologia vegetal. Artemed. $719 p$.

Well R (1991) Soybean growth response to plant density: relationships among canopy photosynthesis, leaf area and light interceptation. Crop Science 31:755$-761$. 